Economics Development Analysis Journal 9 (2) 2020

\title{
Determinant of Willingness to Pay Health Insurance Contribution to Informal Workers
}

\author{
${ }^{1}$ Witati ${ }^{凶},{ }^{2}$ Phany Ineke Putri
}

${ }^{1,2}$ Economics of Development Department, Universitas Negeri Semarang

\begin{abstract}
Article Info Abstract

Article History Received December 2019 Accepted March 2020 Published May 2020

The purpose of this study was to analyze the willingness to pay contributions of informal workers and the factors that affect the willingness to pay contribution of Badan Penyelenggara Jaminan Sosial (BPJS) Kesehatan for informal workers in Brebes Regency. Descriptive research with quantitative approach method is used in this study. Data analysis method uses logistic regression method. The results showed that 71 respondents were willing to pay contribution of Badan Penyelenggara Jaminan Sosial (BPJS) Kesehatan for the sustainability of the program and improve the quality of service facilities and 29 respondents said they were not willing to pay. Factors that have a significantly affect on willingness to pay for informal workers are income variable, number of family members, and history of catastrophic disease. Whereas the factors that have no significant on

Keywords:

Health Insurance, Informal Workers, Willingness to Pay willingness to pay are the last education variable and knowledge. The policy implication for local governments is to increase productivity in the informal sector which aims to increase income of informal workers and re-record Pekerja Bukan Penerima Upah (PBPU) participants who are economically incapable to be transferred to Penerima Bantuan Iuran (PBI) participants. Increase knowledge related to the importance of paying contributions to Pekerja Bukan Penerima Upah (PBPU) participants by Badan Penyelenggara Jaminan Sosial (BPJS) Kesehatan.
\end{abstract}

\footnotetext{
${ }^{\square}$ Faculty of Economics UNNES, Sekaran, Gunungpati,

Semarang, 50119

E-mail: witati1306@gmail.com
} 


\section{INTRODUCING}

Each country are responsible and obliged to provide guarantee for the health and welfare on every citizens, the obligation is explained in the law both internationally and nationally is in (the Universal Declaration of human rights, 1948) Article 25 paragraph 1 and (Law Number 36 of 2009 concerning Health, 2009) article 5. The existence of these obligations, Indonesian state established a program that provides social security to the public, called The National Health Security Jaminan Kesehatan Nasional (JKN) program. The JKN program is a compulsory social health insurance and it is part of the National Social Security System Sistem Jaminan Sosial Nasional (SJSN). The target of the Jaminan Kesehatan Nasional (JKN) program is the achievement of Universal Health Coverage (UHC) or the inclusion of a comprehensive national participant in 2019.

Badan Penyelenggara Jaminan Sosial (BPJS) Kesehatan is Social Security Adminisrative Bodies, it is the organizer of the Jaminan Kesehatan Nasional (JKN) program. Participant of Badan Penyelenggara Jaminan Sosial (BPJS) Kesehatan is divided into 2 segments are the Penerima Bantuan Iuran (PBI) participant and non-contribution beneficiaries (non PBI) participant consisting of Pegawai Penerima Upah (PPU), non-wage recipients participants
(PBPU), and not worker participant (Bukan Pekerja). After operating for 4 years, since 2014 to 2017, the number of JKN participants in 2017 has reached 187,982,949 participants, which means that is 72.9 percent of Indonesia's population have become Jaminan Kesehatan Nasional (JKN) participants while 27.1 percent of the population has not participated.

Based on table 1 shows the development of the number of Jaminan Kesehatan Nasional (JKN) program participants experiencing a significant increase. In 2014 to 2017 the number of Jaminan Kesehatan Nasional (JKN) participants was dominated by PBI APBN participants, where in 2017 the number of participants reached 92.380.352 participants. While number of participants needs to be increased is Pekerja Bukan Penerima Upah (PBPU) participants in which at only 25.397 .828 participants.

Efforts to achieve the Jaminan Kesehatan Nasional (JKN) program, participation is not only required for formal workers, but workers who work in the informal sector or commonly referred to as informal workers are also required to become Badan Penyelenggara Jaminan Sosial (BPJS) Kesehatan. participants. Informal workers included in Pekerja Bukan Penerima Upah (PBPU) participants where Pekerja Bukan Penerima Upah (PBPU) participant in 2017 covered only 25.397.828 participants.

Table 1. Development Membership Coverage of Jaminan Kesehatan Nasional Program for 2014 - 2017 (in thousand)

\begin{tabular}{lllll}
\hline Participant & 2014 & 2015 & 2016 & 2017 \\
\hline PBI of National budget (PBI APBN) & 86,400 & 87,829 & 91,099 & 92,380 \\
PBI of Regional governmnet budget (PBI APBD) & 8,767 & 11,171 & 15,415 & 20,305 \\
PPU & 24,327 & 37,862 & 41,027 & 44,891 \\
PBU & 9,053 & 14,962 & 19,366 & 25,398 \\
Not worker & 4,876 & 4,967 & 5,061 & 5,008 \\
Amount & 133,424 & 156,790 & 171,939 & 187,983 \\
\hline
\end{tabular}

Source: Badan Penyelenggara Jaminan Sosial (BPJS) Kesehatan , 2018

According to statistics the circumstances of labor Indonesia in February (2018) refers to showed in February 2018 is 53.09 million (41.78 percent) of the population working in the formal sector and 73.98 million (58.22 percent) of the population works in informal sector so that 
workers in Indonesia is dominated by informal workers. It is showed still of many informal workers who have not become participants, although many of informal workers assured in the contribution beneficiaries participants both PBI APBN or PBI APBD. Management groups of participants from the informal workers or PBPU participants is a big challenge faced by Badan Penyelenggara Jaminan Sosial (BPJS) Kesehatan to achieve the Universal Health Coverage Jaminan Kesehatan Nasional (JKN) program on January 1, 2019.

In addition to low participation in Pekerja Bukan Penerima Upah (PBPU) participants, collectability dues Pekerja Bukan Penerima Upah (PBPU) participants also low, until June 2018, agregate collectability contributions Jaminan Kesehatan Nasional (JKN) participants has reached 99 percent, but collectability contribution Pekerja Bukan Penerima Upah
(PBPU) participants is need to be optimized, is 54 percent (Badan Penyelenggara Jaminan Sosial (BPJS) Kesehatan , 2018). According to the Director of Primary Badan Penyelenggara Jaminan Sosial (BPJS) Kesehatan , Fachmi Idris, PBPU participants are a segment of participants that most arrears of contribution and have trend a low of submission. There are two reasons why the level of submission of low Pekerja Bukan Penerima Upah (PBPU) participant, the first is that there are some participants who are unable to pay and the second is the willingness to pay lower (Setiawan, 2017). Willingness to pay is the maximum price that a buyer is willing to pay for an item/service. Willingness to pay of consumers for the various goods and services they consume will present consumer demand for goods and services. The number of requests for each item is the number of items that the buyer can wants and afford (Mankiw, 2006).

Table 2. Comparison Contribution Revenue Rencana Kegiatan dan Anggaran Tahunan (RKAT) and Realization until 31 December 2017 (in million IDR)

\begin{tabular}{lllll}
\hline No. & Type of Participants & RKAT 2017 & $\begin{array}{l}\text { Realization } \\
\text { 31 December 2017 }\end{array}$ & \%ntil \\
\hline A & PBI of national budget (PBI APBN) & $25.502,424$ & $25,362,816$ & 99.45 \\
B & Non PBI & & \\
& 1. PPU & & & \\
& a. PPU of Government & $14,660,062$ & $13,820,774$ & 94.28 \\
& b. PPU of Business Entity & $28,707,685$ & $21,490,531$ & 74.86 \\
& Sub-total PPU & $43,367,747$ & $35,311,306$ & 81.84 \\
& 2. PBPU & $10,382,858$ & $6,716,609$ & 64.69 \\
& 3. Not worker & $1,799,501$ & $1,650,705$ & 91.73 \\
& Sub total B & $55,550,106$ & $43,678,620$ & 78.63 \\
C & Population registered by the Regional & $4,637,566$ & $5,205,205$ & 112.24 \\
& Government (PBI APBD) & & & \\
& Total (A + B + C) & $85,690,096$ & $74,246,641$ & 86.65 \\
\hline
\end{tabular}

Source: Badan Penyelenggara Jaminan Sosial (BPJS) Kesehatan , 2017

In Table 2 shows the revenue of contribution derived from PBPU participants only $64,69 \%$ of the target of RKAT 2017, there is the lowest achievement compared with other participants of Jaminan Kesehatan Nasional (JKN) program. The low achievement resulted in a high number of PBPU participants being temporarily dismissed from their health insurance.Since operating in 2014, almost everyyear Badan
Penyelenggara Jaminan Sosial (BPJS) Kesehatan has a budget deficit. Table 3 shows the ratio of the cost of benefits to conribution realization in 2014 up to 2017 showed the development of which is likely to increase despite the downturn in 2016, the tendency of increase in the ratio of claims indicates that during Badan Penyelenggara Jaminan Sosial (BPJS) Kesehatan had operated 
cost benefit incurred it is larger than contribution fees received.

Table 3. Ratio of Benefit Costs to Revenue Contribution Realization in 2014-2017 (in million IDR)

\begin{tabular}{llllll}
\hline No & Description & 2014 & \multicolumn{1}{c}{2015} & 2016 & 2017 \\
\hline 1. & Contribution income & 40.716 .862 & 52.778 .121 & 67.797 .414 & 74.246 .641 \\
2. & Payment of benefits & 42.658 .702 & 57.083 .273 & 67.247 .884 & 84.444 .864 \\
& Claim Ratio (\%) & 104.76 & 108.16 & 99.19 & 113,74 \\
\hline
\end{tabular}

Source: Dewan Jaminan Sosial Nasional, 2017.

Since operating in 2014, almost every year Badan Penyelenggara Jaminan Sosial (BPJS) Kesehatan has a budget deficit. Table 3 shows the ratio of the cost of benefits to conribution realization in 2014 up to 2017 showed the development of which is likely to increase despite the downturn in 2016, the tendency of increase in the ratio of claims indicates that during Badan Penyelenggara Jaminan Sosial (BPJS) Kesehatan had operated cost benefit incurred it is larger than contribution fees received.

The budget deficit contribution to still many of participants are arrears especially participants who are PBPU and Bukan Pekerja participants. In addition there are many participants who are in arrears, the other is the cause of the budget deficit is define of contribution by BPJS not accordance with actuarial calculations by National Social Security Council. The arrears of participants contributions become one of the factors that caused of deficit budget due to low levels of collectability that the funds should be used to facilitate participants of Badan Penyelenggara Jaminan Sosial (BPJS) Kesehatan will be obstructed because of the contribution arrears.

Central Java Province is a province that has JKN participants which is lower than national figures. Total population of Central Java is 36.2 million population, people who participated in the JKN program reached 24.1 million or 69 percent have already registered (Laeis, 2017). One of the aims of establishing the $\mathrm{JKN}$ program is to achieve the highest degree of health. According Central Java Province of Central Bureau of Statistics (2017), city which has the highest life expectancy is Sukoharjo
Regency amounted to 77.46 years and city which has the lowest life expectancy is Brebes Regency amounted to 68.61 years.

Brebes Regency is a district that has the lowest life expectancy among districts/cities in Central Java Province. Low levels of life expectancy Brebes Regency population showed low level degree of health in Brebes Regency be compared districts/cities in Central Java Province. According to the Badan Penyelenggara Jaminan Sosial (BPJS) Kesehatan of Brebes Regency (2018), in 2017 the population of Brebes Regency have already participants are 1.49428 million populations, there is compared with a population of Brebes Regency in 2017 is $1,796,004$ populations, the number of populations who have covered in the JKN program are 83 percent.

Participants in the Badan Penyelenggara Jaminan Sosial (BPJS) Kesehatan of Brebes Regency have low awareness of paying contribution. According to the Badan Penyelenggara Jaminan Sosial (BPJS) Kesehatan Office of the Tegal Branch, up to April 2018 the number of participants in arrears was 291,933 participants in the three regions handled. Details of the number of participants who are in arrears in the Badan Penyelenggara Jaminan Sosial (BPJS) Kesehatan of Tegal Branch are Tegal city is 28.993 participants, Tegal regency is 105.347 participants and Brebes Regency is 97.593 participants. Brebes Regency is in the second position with a total of 97.593 participants in arrears (Faiz, 2018). Based on Table 4 shows the comparison of independent participants with the number of participants who are in arrears in Badan Penyelenggara Jaminan Sosial (BPJS) 
Kesehatan of Tegal Branch. Brebes Regency is not the regency that has the highest number of independent participants, but based on the comparison shows that Brebes Regency is the regency that has the highest percentage in theratio of the number of independent participants with the number of participants in arrears among the regency/cities in the working area of Badan Penyelenggara Jaminan Sosial (BPJS) Kesehatan of Tegal Branch. The high percentage of the comparison of the number of independent participants with the number of participants who are in arrears Badan Penyelenggara Jaminan Sosial (BPJS) Kesehatan in Brebes Regency shows the low submission of PBPU participants to pay contributions, which means the PBPU/Independent participant of Badan Penyelenggara Jaminan Sosial (BPJS) Kesehatan have low willingness to pay contribution of Badan Penyelenggara Jaminan Sosial (BPJS) Kesehatan contributions in Brebes Regency.

Table 4. Comparison of the Number of Independent Participants and the Number of Participants in Arrears of Contributions at the Badan Penyelenggara Jaminan Sosial (BPJS) Kesehatan Tegal Branch

\begin{tabular}{lllrlrc}
\hline No & Regency / City & $\begin{array}{l}\text { Number of Independent } \\
\text { Participants }\end{array}$ & $\begin{array}{l}\text { Number of Participants in } \\
\text { Arrears }\end{array}$ & \% \\
\hline 1. & Brebes Regency & 371.521 & 97.593 & & $26 \%$ \\
2. & Tegal City & 112.494 & 28.993 & & $25 \%$ \\
3. & Tegal Regency & 440.945 & 105.347 & & $23 \%$ \\
\hline
\end{tabular}

Source: Central Java Province of Central Bureau of Statistics, 2019 (Data processed)

Willingness To Pay (WTP) calculates how far the ability of a person or community in the aggregate to spend and pay of money in order to improve environmental conditions to fit the expected environmental conditions (Pungky \& Puspitasari, 2014). Every buyer is willing to buy a product if the price of these goods under the willingness to pay, and if the price of these goods on prices willingness to pay so the buyer is not going to buy goods and to buy or not if the price of this item at a price of willingness to pay (Mankiw N., 2006).

Informal workers in Brebes Regency are dominated by workers who work in the agricultural sector are 312,252 workers. The informal workers is generally workers who have low levels of education so that the productivity of informal workers is also low which results in low income of informal workers. Indicators to determine of income someone in an area can shows from the region per capita income. According to Brebes Regency of Central Bureau of Statistics (2017) Brebes Regency has a per capita income of Rp.1.855.403 per month. According to Andika WP in Aryani (2013) said that family income is strongly associated with poverty. According to Central Java Province of Central Bureau of Statistics (2019) Brebes Regency is a regency that has the third highest percentage of poor population in Central Java

Province is 19.14 percent. This shows that there are still many people in Brebes Regency who have low income and live in poverty.

Income is one of the main factors for someone to consume. Income on a family going on is allocated in advance for daily basic needs such as eating and drinking, after basic needs are fulfilled then advantages that revenue will be used to meet other needs such as paying health insurance contributions. According to Aryani (2013) the level of income has a significant effect on the amount of willingness to pay for the improvement of class III Badan Penyelenggara Jaminan Sosial (BPJS) Kesehatan services.

Informal workers who have low productivity generally have low incomes. The low productivity of informal workers can be caused by their limited skills. The level of education completed by informal workers can affect the skills they have. According to the Employment Statistics of Brebes Regency (2017) the composition of the percentage of the 
workforce in Brebes Regency is based on last education are elementary school/equal are 67.72 percent, junior high school/equal are 14.68 percent, high school graduate/equal are 12.76 percent, and college high are 4.84 percent. Labor Brebes dominated by workers with equivalent elementary education level that is equal to 67,72 percent of which showed workers in Brebes have less educated. The level of education of a person influences the perception of risk, the degree/ level of aversion take a risk, and the perception of loss, so the higher a person's education will also increase the knowledge and needs about health services which will ultimately impact on the willingness to pay for health insurance (Lofgren, et al. , 2008 ).

The level of education affects a person's skills which ultimately affects their income. Income affects the welfare of a family. The more the number of family members in a family, the more likely there are to be more dependents of family. The number of family dependents increases, then as many family needs that must be fulfilled (Rochaningrum, et al., 2018). The amount of the population that is dependents by the working of age population in an area is shown in the dependency ratio. In 2017, the Brebes Regency had 49.32 percent dependency ratio, which means that every 100 people of productive age in Brebes Regency covered 49 people who were not yet productive and who were considered to be no longer productive (Brebes Regency of Central Bureau of Statistics, 2017).

The greater the number of family members, then the risk of the dependents of health care or medical expenses is relatively high compared to families with few family members.

According to Babantunde, et al. (2012) household that have a family member is $4-6$ member has a willingness to pay insurance contributions health higher than households with family members more than 6 members. The registration of participants in the Badan Penyelenggara Jaminan Sosial (BPJS) Kesehatan program is adjusted to the number of family members so that the more family members, the more fees are paid.
Paid of Badan Penyelenggara Jaminan Sosial (BPJS) Kesehatan contributions is a consideration for someone to become a Badan Penyelenggara Jaminan Sosial (BPJS) Kesehatan participant. The low achievement of PBPU participants is an indication of the not optimal socialization by Badan Penyelenggara Jaminan Sosial (BPJS) Kesehatan (Siswoyo, et al., 2015). The more information about Badan Penyelenggara Jaminan Sosial (BPJS) Kesehatan a person gets, the better the person's knowledge of Badan Penyelenggara Jaminan Sosial (BPJS) Kesehatan . Informal workers or PBPU participants are Badan Penyelenggara Jaminan Sosial (BPJS) Kesehatan participants who pay contributions independently, so knowledge about contribution payments is very important for PBPU participants. Research by Kusumaningrum and Azinar (2018) shows that knowledge can increase the willingness and awareness to be participants JKN program than people who have less knowledge well.

One of the factors a person is a participant in Badan Penyelenggara Jaminan Sosial (BPJS) Kesehatan is to reduce the burden of medical expenses consequence has certain diseases, especially catastrophic diseases that need a lot of costs.

Based on Badan Penyelenggara Jaminan Sosial (BPJS) Kesehatan data (2019) catastrophic disease consumes 25 percent of the total proportion of funding as a agregate. According to Sartono as Head of the Brebes Regency of Health Office declare that the level of NonCommunicable Diseases or catastrophic diseases in Brebes Regency tended to increase and had been threatening since a young age, where hypertension was the disease most experienced by Brebes Regency residents (Tribun Jateng.com, 2019). According to the Brebes Regency Health Office (2019) from 2013 to 2018 the prevalence of non-communicable diseases in Brebes Regency has increased. The need for insurance is not include primary needs so that people who need information about insurance is people who need health insurance services (Hermawati, 2013).

Based on the background and formulation of the problems that have been presented, the 
aims of this study are (1) Knowing the number of informal workers who are willing and not willing to pay Badan Penyelenggara Jaminan Sosial (BPJS) Kesehatan for sustainability program and improve the quality of facilities and infrastructure services health. (2) Analyzing the factors that influenceaffect the willingness to pay Badan Penyelenggara Jaminan Sosial (BPJS) Kesehatan contributions to informal workers in Brebes Regency.

\section{RESEARCH METHOD}

The method used in this research is descriptive research method with a quantitative approach. Descriptive approach is used with the aim of analyzing the factors that affect willigness to pay of Badan Penyelenggara Jaminan Sosial (BPJS) Kesehatan contributions to informal workers whose variables are not included in the econometrics model. Quantitative approach is used to measure the effect of independent variables, are income variable, last education, number of family members, knowledge, and history of catastrophic disease on the dependent variable that is willingness to pay and to test the hypothesis that has been set. The hypothesis in this study are hypothesis of income variable are the null hypothesis $\left(\mathrm{H}_{0}\right)$ mentions that it is suspected that the income variable has not affect on the WTP variable and the alternative hypothesis $\left(\mathrm{H}_{\mathrm{a}}\right)$ mentions that it is suspected that the income variable has affect on the WTP variable.

Hypothesis of the last educational are the null hypothesis $\left(\mathrm{H}_{0}\right)$ mentions that it is suspected that the last educational variable has not affect on the WTP variable and alternative hypothesis $\left(\mathrm{H}_{\mathrm{a}}\right)$ mentions that it is suspected that the last educational variable has affect on the WTP variable.

Hypothesis of the number of family members are the null hypothesis $\left(\mathrm{H}_{0}\right)$ mentions that it is suspected that the number of family members has not affect the WTP variable and alternative hypothesis $\left(\mathrm{H}_{\mathrm{a}}\right)$ mentions that it is suspected that the number of family members has affect on the WTP variable.
Hypothesis of knowledge are the null hypothesis $\left(\mathrm{H}_{0}\right)$ mentions that it is suspected that the knowledge variable has not affect on the WTP variable and alternative hypothesis $\left(\mathrm{H}_{\mathrm{a}}\right)$ mentions that it is suspected that the knowledge variable has affect on the WTP variable.

Hypothesis of the history of catastrophic disease are the null hypothesis $\left(\mathrm{H}_{0}\right)$ mentions that it is suspected that the history of catastrophic disease variable has not affect on the WTP variable and alternative hypothesis $\left(\mathrm{H}_{\mathrm{a}}\right)$ mentions that it is suspected that the history of catastrophic diseases variable has affect on the WTP variable.

The population in this study were PBPU participants in Badan Penyelenggara Jaminan Sosial (BPJS) Kesehatan of Brebes Regency, which totaled 128.158 participants. The technique of determining the sample using a purposive sampling technique by determining the number of samples using the slovin formula as many as 100 samples. The data used in this study are secondary data and primary data obtained from 100 respondents who are informal workers registered as PBPU participants in Badan Penyelenggara Jaminan Sosial (BPJS) Kesehatan of Brebes Regency.

The study was conducted at Brebes Regional Hospital, considering that Brebes Regional Hospital is a third-level health service facility and type B hospital that has the most complete facilities in Brebes Regency. In its implementation, the Health BPJS uses a referral system where if patients cannot be treated at the first and second health facilities, they will be referred to a third level health facility. So that patients come from various regions in Brebes Regency. Data is collected by using questionnaires and interviews.

Data processing and analysis techniques used in this study use logistic regression. This method is used to find out what factors influence the decision of informal workers to pay Badan Penyelenggara Jaminan Sosial (BPJS) Kesehatan contributions. The logistic regression models in this study are as follows:

$$
\begin{aligned}
& \operatorname{Ln} \frac{P i}{1+P i}=\beta_{0}+\beta_{1} \text { Pend }+\beta_{2} \mathrm{PT}+\beta_{3} \mathrm{JAK}+\beta_{4} \text { Tahu } \\
& +\beta_{5} \mathrm{RPK}+\varepsilon
\end{aligned}
$$


Where $\operatorname{Ln} \frac{P i}{1+P i}$ is the probability of informal workers to be willing to pay Badan Penyelenggara Jaminan Sosial (BPJS) Kesehatan contributions or not willing to pay Badan Penyelenggara Jaminan Sosial (BPJS) Kesehatan contributions. $\beta_{0}$ constants, $\beta_{1}, \ldots, \beta_{5}$ is coefficient, Pend is the level of income, PT is last education complete, JAK isnumber of family member, Tahu is knowledge, RPK is history of catastrophic desease, $\varepsilon$ is error. Dependent variable is the willingness to pay to Badan Penyelenggara Jaminan Sosial (BPJS) Kesehatan contributions of informal workers (willingness to pay). Consists of: 1 for If willing to pay dues; 0 for If not willing to pay dues.

The independent variable are income, last educational, number of family members, knowledge, and History of catastrophic disease. Income variable, consisting of:

1 for Rp.1.000.000-Rp.2.000.000;

2 for Rp.2.000.001-Rp.3.000.000;

3 for Rp.3.000.001-Rp.4.000.000; and

4 for Rp.4.000.001.

Last education variable, consisting of: 1 for Not attending school / not completing elementary school; 2 for Basic education (elementary and junior high school); 3 for Middle education (high/vocational school); and 4 for Higher education.

The number of family members variable, calculated in units of people. Knowledge variable, consisting of: 1 for If knowledge is lack; 2 for If knowledge is enough; 3 for If knowledge is good. History of catastrophic disease, consisting of: 0 for If not have a history of catastrophic disease; 1 for If have a history of catastrophic disease

Statistical criterion testing methods used in logistic regression are Goodness of fit test, model accuracy test, McFadden R-squared test, $\mathrm{z}$ test, and LR statistics test. Goodness of fit test is used to test the zero hypothesis that there is no difference between the models with the data so that the model can be said to fit. Model Accuracy Testi is used to show how well the model prediction results and as a measure of model accuracy . MCFadden R-squared test is used to measure how much the variation of the dependent variable can be explained by the independent variables in the model used. The $\mathrm{z}$ test is used to test whether the independent variables individually have a significant effect on the dependent variable. LR test statistic is used to test whether the independent variables together have a significant effect on the dependent variable.

\section{RESULTS AND DISCUSSION}

Data analysis method used in this research is logistic regression method using Eviews software. The logistic regression method was used to analyze the affect of income, the last education, the number of family members, knowledge, and history of catastrophic disease on the variable willingness to pay

Table 5 . Logistic Regression Results

\begin{tabular}{lllll}
\hline Variable & Coefficient & Std. Error & z-Statistic & Prob. \\
\hline $\mathrm{C}$ & -2.656728 & 2.114708 & -1.256310 & 0.2090 \\
Income & 1.566618 & 0.508117 & 3.083186 & $0.0020^{*}$ \\
Last Education & 0.882609 & 0.536375 & 1.645508 & 0.0999 \\
Number of Family members & -0.886576 & 0.343451 & -2.581375 & $0.0098^{*}$ \\
Knowledge & 0.589663 & 0.478908 & 1.231267 & 0.2182 \\
History of catastrophic disease & 2.174359 & 0.716860 & 3.033170 & $0.0024^{*}$ \\
\hline
\end{tabular}

McFadden R-squared

0.461540

LR statistic

55.58346

Prob(LR statistic)

0.000000 


\begin{tabular}{ll}
\hline HL Goodness of fit Statistic & 0.7656 \\
Percently correctly predicted & $88 \%$ \\
\hline
\end{tabular}

Source: Primary Data, 2019 (Data processed)

Based on the results of logistic regression calculations, the value of MCFadden R-Squared is 0.461540 or $0.46 \%$, it can be interpreted that the variable income, last education, the number of family members, knowledge, and history of catastrophic disease can explain the willingness to pay variable is 46 percent and the remaining 54 percent is explained by other variables outside the model.

Based on logistic regression calculation value HL Goodness of fit statistic is $0.7656>$ 0.05 , which means that zero hipotesis received it is shows that the model is able to predict the value of his observations so that the model received caused fits to the data observation. While the value of percently correctly predicted is $88 \%$ so that the model concluded quite well.

Based calculation of logistic regression, the value of Prob LR statistic is 0.000000 less than the alpha value of 0.05 point it is shows that variable income, last education, the number of family members, knowledge, and a history of catastrophic disease together have a significant affect on the variables willingness to pay.

Tabel 3 shows the results of logistic regression analysis, based regression model, then regresi models are as follows:

Ln $\frac{P i}{1+P i}=-2.6567+1.5666$ Pend +0.8826 PT $0.8865 \mathrm{JAK}+0.5896 \mathrm{Tahu}+2.1743 \mathrm{RPK}+$

Based on the results of data processing in table 3 , the probability value of each independent variable are income is 0.0020 ; last education is 0.0999 ; the number of family members is 0.0098 ; knowledge is 0.2182 ; and history of catastrophic disease is 0.0024 . Variables have a significant effect if the probability value is less than the alpha value, where in this study the alpha is 5 percent or 0.05. Based on the description of the probability value of each of these variables, the variables that significantly affect on the wilingness to pay are income variables is 0.0020 , the number of family members is 0.0098 , and a history of catastrophic disease is 0.0024 because the probability value is less than alpha value which is 0.05 . Last education variable is 0.0999 and knowledge is 0.2182 have not significant affect on the willingness to pay caused the probability value is more than the alpha of 0.05 .

Based partial significance test, then the hypothesis testing that has been formulated is the null hypothesis $\left(\mathrm{H}_{0}\right)$ mentions that it is suspected that the income variable has not affect on the WTP variable. The alternative hypothesis $\left(\mathrm{H}_{\mathrm{a}}\right)$ mentions that it is suspected that the income variable has affect on the WTP variable. Based on table 3 the Prob z-statistic income variable is 0.0020 less than the alpha value of 0.05 , it can be said that the alternative hypothesis $\left(\mathrm{H}_{\mathrm{a}}\right)$ is accepted. It was concluded that the income variable has affect to WTP variable.

The null hypothesis $\left(\mathrm{H}_{0}\right)$ mentions that it is suspected that the last educational variable has not affect on the WTP variable. The alternative hypothesis $\left(\mathrm{H}_{\mathrm{a}}\right)$ mentions that it is suspected that the last educational variable has affect on the WTP variable. Based on table 3 the Prob zstatistic last education variable is 0.0999 more than the alpha value of 0.05 , it can be said that the alternative hypothesis $\left(\mathrm{H}_{\mathrm{a}}\right)$ is rejected. It was concluded that the last educational variable has not affect to WTP variable.

The null hypothesis $\left(\mathrm{H}_{0}\right)$ mentions that it is suspected that the number of family members has not affect the WTP variable. The alternative hypothesis $\left(\mathrm{H}_{\mathrm{a}}\right)$ mentions that it is suspected that the number of family members has affect on the WTP variable. Based on table 3 the Prob zstatistic number of family members variable is 0.0098 less than the alpha value of 0.05 , it can be said that the alternative hypothesis $\left(\mathrm{H}_{\mathrm{a}}\right)$ is accepted. It was concluded that the number of family members variable has affect to WTP variable.

The null hypothesis $\left(\mathrm{H}_{0}\right)$ mentions thati it is suspected that the knowledge variable has not 
affect on the WTP variable. The alternative hypothesis $\left(\mathrm{H}_{\mathrm{a}}\right)$ mentions that it is suspected that the knowledge variable has affect on the WTP variable. Based on table 3 the Prob z-statistic knowledge variable is 0.2182 is more than the alpha value of 0.05 , it can be said that the alternative hypothesis $\left(\mathrm{H}_{\mathrm{a}}\right)$ is rejected. It was concluded that the knowledge variable has not affect to WTP variable.

The null hypothesis $\left(\mathrm{H}_{0}\right)$ mentions that it is suspected that the history of catastrophic diseases variable has not affect on the WTP variable. The alternative hypothesis $\left(\mathrm{H}_{\mathrm{a}}\right)$ mentions that it is suspected that the history of catastrophic diseases variable has affect on the WTP variable. Based on table 3 the Prob z-statistic the history of catastrophic diseases variable is 0.0024 less than the alpha value of 0.05 , it can be said that the alternative hypothesis $\left(\mathrm{H}_{\mathrm{a}}\right)$ is accepted. It was concluded that the history of catastrophic diseases variable has affect to WTP variable.

Table 6. Willingness to Pay of Informal workers to Badan Penyelenggara Jaminan Sosial (BPJS)

Kesehatan Contributions

\begin{tabular}{llll}
\hline No. & Willingness to Pay & amount & $\%$ \\
\hline 1 & Willing & 71 & $71 \%$ \\
2 & Not willing & 29 & $29 \%$ \\
& Amount & 100 & $100 \%$ \\
\hline
\end{tabular}

Source: Primary data processed, 2019

Based on data obtained from 100 respondents, 71 respondents said they were willing to pay Badan Penyelenggara Jaminan Sosial (BPJS) Kesehatan contributions for the sustainability of the program and improve the quality dan infrastructure service and 29 respondents said they were not willing to pay Badan Penyelenggara Jaminan Sosial (BPJS) Kesehatan contributions. The reason respondents are not willing to pay Badan Penyelenggara Jaminan Sosial (BPJS) Kesehatan contributions is that respondents are unable to pay Badan Penyelenggara Jaminan Sosial (BPJS) Kesehatan contributions so that the inability causes respondents not to pay contributions. In addition, service quality is also one of the reasons why respondents are not willing to pay, unsatisfactory service quality makes respondents not willing to pay contribution.

Based on the results of hypothesis testing on 5 independent variables, the variables that have significantly affect the dependent variable are income, number of family members, and history of catastrophic disease variable. While the variables that have no significant affect are the last education and knowledge variables.

Income has a significant affect on the willingness to pay of informal workers to Badan Penyelenggara Jaminan Sosial (BPJS) Kesehatan contributions. Income has a positive relationship to willingness to pay. This means that the higher the family income, then the higher the probability of informal workers to be willing to pay Badan Penyelenggara Jaminan Sosial (BPJS) Kesehatan contributions assuming other factors are considered constant. The coefficient of income in logistic regression is 1.5666 with antilog value of 4.790 so the odds ratio of income variable is 4.790 , meaning the probability of informal workers willing to pay Badan Penyelenggara Jaminan Sosial (BPJS) Kesehatan contributions increases of 4,790 times for every 1 million increase in income level, assuming other factors are considered constant.

The results of this study are the same as research of Aryani and Muqorrobin (2013) which states that income has a significant affect on the amount of willingness to pay individuals to improve Badan Penyelenggara Jaminan Sosial (BPJS) Kesehatan services in class III. Research in Ethiopia also pointed outcome that is the same that farmers income has positive affect on willingness to pay both voluntary insurance and compulsory insurance (Entele \& Emodi, 2016).

According to Keynes theory income is one of the important factors influencing consumer demand for goods and services, assuming ceteris paribus. Income is an important factor in measuring someone's willingness to pay for goods or services, the higher individual income will present the amount of individual budget for consumption. The higher of income, the greater individual budget for consumption so the higher the ability and opportunity of informal workers to pay Badan Penyelenggara Jaminan Sosial (BPJS) 
Kesehatan contributions. This is because the higher the level of individual income, the easier it is for someone to spend money on other needs such as improving quality (Susanti \& Nihayah, 2019). In addition, high income will also lead individuals to demand for goods and services that are higher for all goods unless the goods are inferior goods and there is no evidence that health insurance is low quality or infrequent goods (Barnighausen et al. 2007 ).

Last education has not significant affect on the willingness to pay Badan Penyelenggara Jaminan Sosial (BPJS) Kesehatan contributions of informal workers. The results are consistent with the results of research Barnighausen (2007), which refers to that education has not significant affect on the willingness to pay health insurance contributions. Research Handayani, et al. (2013) also shows that the level of education has not affect to the willingness to pay health insurance contributions, it is argues that the role of education level is not as big as the ability to pay and the existence of savings to finance health services in determining the willingness to pay health insurance contributions.

In this study, the level of education has not a significant affect on willingness to pay. This study is supported by Fildzah (2016) research on willingness to pay for Badan Penyelenggara Jaminan Sosial (BPJS) Kesehatan facilities in Aceh City which shows that education level variables has not significantly affect to willingness to pay because the research sample is relatively homogeneous. Research conducted by Suhardi et al. (2014) also shows the same thing where there is no relationship between the level of education with the willingness to become a participant in health insurance because the respondent education level is relatively homogeneous where respondents who have Diploma and bachelor/master education are very small compared to high school/equivalent education level and below.

Based on the findings in the field shows that the sample in this study is relatively homogeneous that is from 100 respondents there are 54 respondents or 54 percent of the total respondents have the last level of education at the elementary level of education including elementary and junior high. Informal workers both highly educated and low educated are equally willing to pay Badan Penyelenggara Jaminan Sosial (BPJS) Kesehatan contributions. According to researchers the level of income, and the number of family members have a greater role in determining the willingness to pay Badan Penyelenggara Jaminan Sosial (BPJS) Kesehatan contributions and a history of catastrophic diseases that determine the size of respondents' needs for health services so that affects the willingness to pay health insurance contributions.

The number of family members has a significant affect on the willingness to pay Badan Penyelenggara Jaminan Sosial (BPJS) Kesehatan contributions of informal workers. The relationship between the number of family members with willingness to pay is negatively. It refers that the more the number of family members, the lower the probability of informal workers to be willing to pay Badan Penyelenggara Jaminan Sosial (BPJS) Kesehatan contribution, with assuming other factors held constant.

The coefficient value of the number of family members in logistic regression is -0.8865 with antilog value of 0.412 , so that the odds ratio of variable the number of family members is 0.412 and the coefficient is negative, meaning that the probability of informal workers willing to pay Badan Penyelenggara Jaminan Sosial (BPJS) Kesehatan contributions decreases of 0.412 times for each increase in 1 family member, cateris paribus. The results of this study are the same as those of Babatunde et al. (2012) in Nigeria is households with 4-6 family members have a higher level of willingness to pay compared to households with more than 6 family members.

The large number of family members the more needs needed by the household to fulfilled the needs of life, so the number of family members will affect the head of the family's thoughts on perceptions and risk of losses that arise in making a decision. Regulations in the Badan Penyelenggara Jaminan Sosial (BPJS) Kesehatan obligate all Indonesian citizens to become Badan Penyelenggara Jaminan Sosial 
(BPJS) Kesehatan participants. The existence of these regulations has an impact on the greater number of family members, the more contribution that must be paid.

A family with a large number of family members will have a lower income per capita than a family that has a small number of family members with the same income. Informal workers have an uncertain amount of income each month, this uncertain amount of income influences spending to daily needs of families. When respondents have a high income then the willingness to pay of contribution high that the number of family members much when funds are paid out there so as not to burden households. In contrast, when the respondent's income is low, the respondent will object to the direct payment of one family's contribution, thus affecting the willingness to pay the contribution.

Knowledge of informal workers about Badan Penyelenggara Jaminan Sosial (BPJS) Kesehatan based regression results shows that knowledge has not a significant affect on the willingness to pay Badan Penyelenggara Jaminan Sosial (BPJS) Kesehatan of informal workers. Even though the respondent has good knowledge, knowledge about paying Badan Penyelenggara Jaminan Sosial (BPJS) Kesehatan contributions is only known without action if it is not supported by other factors such as money to pay contributions. Although the respondents know that the Badan Penyelenggara Jaminan Sosial (BPJS) Kesehatan contribution must be paid each month, but only respondent want to pay contribution if respondents when going for treatment only.

Knowledge is not also a major consideration in the willingness to pay Badan Penyelenggara Jaminan Sosial (BPJS) Kesehatan contributions. This research is in line with Sihaloho's research (2015) because in her research it was proven that there has not significant relationship between knowledge and willingness to pay JKN contributions independent participant. Knowledge is not the only determinant in JKN independent participants, where it is suspected that there are inhibiting factors that also affect JKN independent participants, namely the socio- economic condition of the community which means that despite good knowledge but is not a JKN indpendent participant due to socioeconomic conditions that have not been able to pay contributions (Fithriyana, 2019).

The researcher suspects that although the respondent has good knowledge, knowledge about paying Badan Penyelenggara Jaminan Sosial (BPJS) Kesehatan contributions is only known without action if it is not supported by other factors. Although respondents know that Badan Penyelenggara Jaminan Sosial (BPJS) Kesehatan contributions must be paid every month, respondents are only willing to pay Badan Penyelenggara Jaminan Sosial (BPJS) Kesehatan contributions only when they want to seek medical treatment, besides that researchers are of the opinion that knowledge is also not a major consideration in the willingness to pay Badan Penyelenggara Jaminan Sosial (BPJS) Kesehatan contributions. History of catastrophic disease has a significant affect on the willingness to pay Badan Penyelenggara Jaminan Sosial (BPJS) Kesehatan contributions of informal workers. History of catastrophic disease has a positive relationship with willingness to pay. The positive relationship shows that if informal workers have a history of catastrophic disease, it can increase the probability willingness to pay Badan Penyelenggara Jaminan Sosial (BPJS) Kesehatan contribution, assuming other factors held constant.

The coefficient value of historical of catastrophic disease in logistic regression is 2.1743 with the odds ratio of history of catastrophic disease variable is 8. 796 and positive value, meaning that the probability of informal workers willing to pay Badan Penyelenggara Jaminan Sosial (BPJS) Kesehatan contributions is 8,796 times higher for informal workers who has a history of catastrophic disease compared to informal workers that has not history of catastrophic disease, assuming other factors are considered constant. The results of this study are the same as research in Ethiopia which shows that households that have a history of chronic disease have a willingness to pay for health insurance, this is because there is a high 
risk of chronic disease then increasing willingness to pay (Entele \& Emodi, 2016).

The results of this study are in accordance with the theory of Notoatmodjo (2003) that is someone who has a certain disease both suffered by individual and the possibility of derivatives from family members will affect individual behavior for healthy living such as participating in health insurance, one of the forms of participating in health insurance is by pay health insurance contributions. The results of this study also prove the theory of Djuhaeni (2007) which states that health insurance facilitates the community in reducing the burden on public health costs through out of pocket because the number of sick dependents that require a lot of costs and difficult to predict the arrival.

Respondents who have a history of catastrophic disease are willing to pay Badan Penyelenggara Jaminan Sosial (BPJS) Kesehatan contributions every month because they want to reduce the burden of medical expenses incurred due to catastrophic disease, by paying monthly contributions, respondents feel helped in reducing the risk of an unpredictable cost burden. In contrast to individuals who do not have a history of chronic illnesses or chronic disease derivatives from their families will have a willingness to pay lower health insurance contributions because of the low risk of loss from illness so respondents do not feel the need for health care services .

\section{CONCLUSION}

Based on the analysis that has been done, it can be concluded that based on the willingness to pay Badan Penyelenggara Jaminan Sosial (BPJS) Kesehatan contributions of informal workers for the sustainability of the program and improve the quality services of facilities and infrastructure health, 71 informal workers stated they were willing while 29 informal workers stated they were not willing to pay. Willingness to pay Badan Penyelenggara Jaminan Sosial (BPJS) Kesehatan contributions to informal workers is affect by various factors. Factors that have affect the willingness to pay Badan Penyelenggara Jaminan Sosial (BPJS) Kesehatan contributions of informal workers are income, number of family members, and history of catastrophic disease variables. While the last education and knowledge variables have not affect the willingness to pay Badan Penyelenggara Jaminan Sosial (BPJS) Kesehatan contributions of informal workers.

Based on the results of the research, discussion and conclusions obtained, the suggestion that can be given is that the Brebes Regency Government increases the welfare of informal workers by increasing productivity in the informal sector so that it can increase the income of informal workers and the Brebes Regency Government can re-check PBPU participants who are unable economy and unable to pay Badan Penyelenggara Jaminan Sosial (BPJS) Kesehatan contributions to be transferred to PBI participants. In addition to the efforts made by the local government, the actions taken by Badan Penyelenggara Jaminan Sosial (BPJS) Kesehatan to increase the willingness to pay PBPU participants also need to be done. BPJS can Increase knowledge related to the importance of paying contributions to PBPU participants. This socialization can be done through mass media and through JKN cadres that have been formed. In other words, the Badan Penyelenggara Jaminan Sosial (BPJS) Kesehatan increases the role of JKN cadres in an effort to increase the collectibility of contributions and increase PBPU participant awareness. Efforts to increase the awareness of informal workers/PBPU participants in paying contributions do not only need to be known for the factors that influence it. The maximum amount/price that is willing to be paid by PBPU participants is also an important thing to be known to both the Badan Penyelenggara Jaminan Sosial (BPJS) Kesehatan, regional government and related institutions. Weaknesses in this study is that the maximum amount of Badan Penyelenggara Jaminan Sosial (BPJS) Kesehatan contributions is not yet known to be paid by informal workers or PBPU participants, therefore for further researchers to be able to add an analysis of the willingness to pay Badan Penyelenggara Jaminan Sosial (BPJS) Kesehatan contributions to informal workers so that the 
maximum price who are willing to be paid by informal workers or PBPU participants.

\section{REFERENCES}

Aryani, MA, \& Muqorrobin, M. (2013). Determinants Willingness to Pay (WTP) Contribution of BPJS Participant. Journal of Economics and Development Studies, Volume 14, No. 1. 44-57. Universitas Muhammadiyah Yogyakarta.

Babatunde, O., et al. (2012). Willingness to Pay For Community Health Insurance and Its Determinats Among Household Heads in Rural Community in North Central Nigeria. International Review of Social Sciences and Humanities, Volume 2 No. 2. 133-142. Ilorin: University of llorin.

Barnighausen, T., Liu, Y., Zhang, X., \& Sauerborn, R. (2007). Willingness to Pay for Social Health Insurance Among Informal Se ctor Workers in Wuhan, China: A Contingent Valuation Study. BMC Health Services Research, Volume 7 No. 114. 1-16. Wuhan: BioMed Central.

Badan Penyelenggara Jaminan Sosial. (2018a). Reaches $99 \%$, Collectability of Contribution JKN-KIS Keep to Increase. https: //bpjskesehatan.go.id/bpjs/index.php/post/r ead/2018/913/Capai-99-Kolektabilitas-IuranJKN-KIS-Terus- didongkrak. (Download on December 25, 2018).

Badan Penyelenggara Jaminan Sosial. (2018b). Program Management Report and the Financial Statements Year 2017 Social Security Health. Jakarta: Badan Penyelenggara Jaminan Sosial (BPJS) Kesehatan Central Office.

Central Statistic Agency. (2018). The state Employment of Indonesia in February 2018. Jakarta: The Central Bureau of Statistics.

Central Statistic Agency. (2018a). Brebes Regency In Figures 2018. Brebes: BPS Brebes.

Central Statistic Agency. (2018b). 2017. Labor Statistics of Brebes. Brebes: BPS Brebes.

Central Statistic Agency. (2019a) . Amount of Non Participant Contribution Recipient BPJS By Regency / City in Central Java province, 2016 $\&$ 2018.

https://jateng.b.go.id/dynamictable/2019/10 /24/584/banyaknya-peserta-non-penerimabantuan-iuran-BPJS-kesehatan-menurutkabupaten-kota-di-provinsi-jawa-tengah-20162018.html. (Download on November 5, 2019)
Central Statistic Agency. (2019b). Percentage of Poor People Regency/City in Central Java province Years 1996-2018. https://jateng.bps.go.id/dynamictable/2019/ 01/29/93/persentase-penduduk-miskinmenurut-kabupaten-kota-di-provinsi-jawatengah-1996-2018.html. (Download on November 7, 2019).

Djuhaeni, H. (2007). Health Insurance and Managed Care. Bandung: Padjadjaran University.

Entele, BR, and Emodi, N. (2016). Health Insurance Technology in Ethiopia: Willingness to Pay and Its Implication for Health Care Financing. American Journal of Public Health Research, Volume 4 No. 3. 98-106. New York: Science and Education Publishing.

Faiz, MI (2018). Hundreds of thousands Residents Still delinquent dues in Badan Penyelenggara Jaminan Sosial (BPJS) Kesehatan Tegal. https: //kumparan.com/panturapost/ratusan-ribuwarga-masih-menunggak-iuran-di-bpjskesehatan-tegal. (Download on December 25, 2018).

Fildzah, S. (2016). Willingness to Pay (WTP) Facilities Health Social Security Agency in Banda Aceh. Essay. Aceh's Syiah Kuala University.

Fithriyana, R. (2019). Relationship of Knowledge and Attitudes About Family Head of National Health Insurance (JKN) with membership in Puskesmas Bangkinang Independently City. PREPOTIF Journal of Public Health, volume 3 No. 2. 1-8. Kampar: University Pahlawan Tuanku Tambusai.

Handayani, E., Gondodiputro, S., \& Saefullah, A. (2013). Factors Affecting Willingness to Pay Dues Public Health Security in Hulu Sungai Selatan. Padjadjaran University Scientific Library. Bandung; Padjadjaran University.

Hermawati, S. (2013). Influence of Gender, Education Level, and Age Of Consciousness Society Insurance in Indonesia. Insurance and Risk Management Journal, Volume 1 No. 1. 53-69. Depok: Gunadarma University.

Kusumaningrum, A., \& Azinar, M. (2018). Public Participation in Jaminan Kesehatan Nasional Independently. HIGEIA Journal of Public Health Research and Development, Volume 2 No. 1. 149-160. Semarang State University.

Laeis, Z. (2017). Badan Penyelenggara Jaminan Sosial (BPJS) Kesehatan Participation Still Less in Central Java. https://jateng.antaranews.com/detail/kepese rtaan-bpjs-kesehatan-di-jateng-masih- 
kurang.html. (Download on December 26, 2018).

Law of the Republic of Indonesia Number. 36 Year 2009 on Health, 2009. Jakarta: propagated by the Ministry of Health.

Lofgren, C., Thanh, NX, Chuc, NT, Emmelin, A., \& Lindholm, L. (2008). People's Willingness to Pay for Health Insurance in Rural Vietnam. BioMed Central, Volume 6 No. 16. 1-16. Vietnam: Hanoi Medical University.

Mankiw, N.Gregory (2006). Introduction to Microeconomics (Principles of economics). Jakarta: Four Salemba.

National Social Security Council. (2017). Achievements and Challenges of the Jaminan Kesehatan Nasional Program. Jakarta: The National Social Security Council.

Notoatmodjo, S. (2003). Education and Health Behavior. Jakarta: PT. Asdi Mahasatya.

Office of Communications and Statistics District of Brebes. (2018). Brebes Regency In Data 2017. Brebes: Office of Communications Information and Statistics Brebes.

Pungky, PP, and Puspitasari, NB (2014). Restructuring Program BPJS with the use of CHAT Experiments and Willingness to Pay Attention to (Willingness to Pay) Against Public Health Insurance Contribution. Industrial Engineering Online Journal, Volume 3 No. 3. 1-7. Semarang: Diponegoro University.

Rochaningrum, E., Nihayah, DM, \& Setyadharma, A. (2018). Factors Influencing Decisions Workforce Degree to Work or No Work. Analysisi Development Economics Journal, Volume 7 No. 1. 60-67. Semarang State University.

Russell, S. (1996). Ability to Pay Health Care: Concept and Evidence. Health Policy and Planning, Volume 11 No. 3. 219-237. United Kingdom:
London School of Hygiene and Tropical Medicine.

Setiawan, SD (2017). Contribution arrears BPJS Participants Translucent Rp. 3,4Triliun.https://ekonomi.kompas.com/rea d/2017/05/23/212619726/tunggakan.iuran.p eserta.bpjs.kesehatan.tembus.Rp.3.4.triliun. (Download on December 26, 2018).

Sihaloho, EN (2015). Determinants Willingness to Pay Dues Independent Jaminan Kesehatan Nasional Participants in the Work Area of Semarang City Health Office. Essay. Semarang State University.

Siswoyo, BE, Prabandari, YS, \& Hendratini, Y. (2015). Awareness Informal Sector Workers Against National Health Insurance Program in the province of Yogyakarta area. Indonesian Health Policy Journal, Volume 4 NO. 4. 118-125. Yogyakarta: Gadjah Mada University.

Suhardi, \& Shaluhiyah, Z. (2014). Analysis of Factors Influencing Willingness Against Self Managed Care Society Becoming Party in Salatiga City area. Indonesian health promotion journal, Volume 9 No. 1, 90-103. Semarang: Diponegoro University.

Susanti, A., \& Nihayah, DM (2019). Analysis of Willingness to Pay (WTP) at Vocational High School. Economic Development Analysis Journal. Volume 8 No. 2. 120-129. Semarang State University.

The Universal Declaration of Human Rights, (1948). Jakarta: propagated by the Commission.

Tribune Jateng.com. (2019). Hypertension Disease plaing Many residents experienced Brebes. Taken back from the Tribune Jateng.com: https://jateng.tribunnews.com/2019/09/25/ penyakit-hipertensi-paling-banyak-dialamiwarga-brebes (Download on November 3, 2019). 